\title{
Development of Scientific Teaching Materials Oriented by Saintificial Approaches to Improve Critical Thinking of Elementary School Students
}

\author{
A.Indra Nihlah Annashih ${ }^{1} \quad$ Tjandra Kirana $^{2} \quad$ Raharjo $^{2}$ \\ 1.Post Graduate, State University of Surabaya, \\ 2.Lecturer, State University of Surabaya
}

\begin{abstract}
This study aims to produce science teaching materials products and related devices such as Learning Implementation Plans (RPP), Student Activity Sheets (LKS), and Test Sheets that are valid, practical, and effective to improve critical thinking of elementary school students. This research was carried out using the 4-D model of Thiagarajan et al., Namely the stage of defining, designing, developing, disseminating and testing in the fifth grade of Dukuhtunggal State Elementary School, Duduklor State Elementary School, Margoanyar Lamongan State Elementary School year 2018/2019 teaching with One-Group Pretest-Posttest Design. The data analysis technique uses quantitative and qualitative descriptive analysis techniques. The results showed: 1) valid, according to the assessment of the three validators with valid categories, 2) practical, according to the assessment of the two observers seen from the activity of students increasing at each meeting and the implementation of RPP, 3) effective, seen from the significant differences between the results of the pretest and posttest tests were students 'critical thinking and the students' positive responses. Based on the results of data analysis, it can be concluded that the development of science-oriented teaching materials scientific approach is valid, practical, and effective to improve critical thinking of elementary school students.
\end{abstract}

Keywords: Development of Teaching Materials, Scientific Approach, Critical Thinking.

DOI: $10.7176 / \mathrm{JEP} / 10-16-01$

Publication date:June $30^{\text {th }} 2019$

\section{INTRODUCTION}

Science in terms can be interpreted as knowledge that includes a variety of natural knowledge. This means that science has an objective and rational nature. In line with the opinion of Djojosoediro (2010: 11) in general, the nature of science has three components, including scientific processes, scientific results, and scientific attitudes. Scientific processes include principles, concepts, laws, and theories. In this activity a high thinking process is needed in order to get new knowledge and experiences that are interesting for students.

According to Rofiah (2013), it shows the importance of thinking learning, namely: (1) thinking is needed as a way to develop perceptions and attitudes that support the creation of a class condition that is good for learning activities; (2) the thought process is needed as a way to acquire and integrate knowledge; (3) the thought process is needed to broaden knowledge; (4) actualize the meaningfulness of knowledge; (5) needed as a way to develop useful thinking behavior. With science education students will be guided to think critically, solve problems, and make decisions that can improve the quality of their lives towards a scientifically learned society.

The development of students' critical thinking skills which is very important should receive more attention in the learning process. Based on experience in the field and analysis from several sources, the inappropriate selection of models, methods and approaches has an impact on the low level of thinking skills of students. Afrizon (2012) states, high-level thinking skills are shown through several aspects, including the ability to think critically, creatively, and be able to solve a problem.

Critical thinking ability must be taught first because it relates to the analysis and evaluation of data, in line with the opinion of Hake (2008): "Science teachers are generally more at ease with critical thinking because it is closely related to analysis and evaluation of data"

Critical thinking ability is the ability of students to make an idea. The ability to think critically is a competency needed in the lives of students (Fahim, 2012). Fatimawati's research (2014) shows that the implementation of critical thinking frameworks is able to build solving life problems and effectively improve the discipline of teachers and students. If the better the orientation of critical thinking skills, the students will be able to overcome various problems in daily life. Considering that critical thinking skills need to be taught because it is not a result obtained from generation to generation, schools should be able to create an interactive learning environment that involves students actively in learning so that they are accustomed to and trained in critical thinking, one of them by means of selection appropriate learning model or approach (Fisher, 2002). However, in reality based on the results of observations and interviews conducted by researchers at the Dukuhtunggal State Elementary School, at Duduklor State Elementary School, and Margoanyar Lamongan State Elementary School it is known that the critical thinking skills of class V students have not been fully trained and taught. This is also 
evident from the low level of activeness, participation and role of students in the learning process, especially when using teaching materials. Teaching materials in the 2013 Curriculum still have not implemented a scientific approach perfectly so that the development of teaching materials is needed to support the material to be taught. If the teacher is able to develop teaching materials that will be used correctly when learning, the achievement of learning objectives will be achieved well, but the reality in the field is the lack of understanding of teachers in implementing learning in accordance with teaching materials that are used to influence student learning success and student understanding. This is evidenced by the value that is still below the KKM, most students get a value less than the standard compote specified, especially on electric and magnetic material.

In improving students' critical thinking and learning capacity, it is necessary to develop 2013 curriculum teaching materials by adjusting the steps of the scientific approach to learning in honing high-level thinking skills (Erten, 2013). Because the learning approach provides opportunities for students and helps students gain an understanding of the scientific method to develop a critical thinking ability, self-regulation, and understanding of a specific topic is to use a scientific approach (Machin, 2014). By using this scientific approach, it is expected to grow critical thinking skills to understand the problems that exist in the environment around students, so that they are more sensitive to changes in the environment and can determine actions that are in accordance with the norm to address these environmental changes.

In the scientific approach to Curriculum 2013, one of the criteria is to inspire and encourage students to think critically, analytically, and precisely as a way of identifying, understanding / interpreting, solving a problem, and applying material to learning (Kemendikbud, 2013). The application of learning using a scientific approach allows students to obtain various important values in the learning process. In the scientific approach includes several activities, among others: observing, asking (questioning), reasoning (associating), experimenting (communicating), and communicating (networking), so that in carrying out some of these activities needed the help of teachers as facilitators, but the teacher in helping / guiding is increasingly minimal due to the higher class of students and the maturing age of the students' thinking. These student activities can be realized in the learning process through the use of science-oriented teaching materials in the scientific approach.

Some topics can be taught in science learning, one of which is electrical and magnetic material. In the 2013 curriculum this material has not implemented the steps of the activities carried out on the scientific approach so that it is necessary to develop teaching materials to facilitate it all. Given this material is one of the complex material for students. Understanding of electrical and magnetic material is not enough just to read the material description, but it is necessary to conduct investigative or experimental activities so that students' understanding of the material becomes more profound. Electrical and magnetic material in the fifth grade elementary school according to the 2013 curriculum includes recognizing energy sources, grouping objects including conductors and electrical insulation, assembling simple series and parallel electrical circuits, changing the shape of electrical energy into other energy and magnetism.

According to Muakhirin (2014) Three components of science learning in the Elementary School Science curriculum, namely: 1) Science learning brings intellectual growth and development of students. 2) Science learning in experimental activities must involve students. 3) Science is what brings about the formation of scientific attitudes, science skills, mastering the basic patterns of science knowledge, and stimulating the growth of a critical and rational attitude towards students in elementary school. Based on these components, the scientific approach oriented teaching materials are arranged to facilitate learning activities in the material of electric and magnetic energy. Students guided by scientific approach-oriented teaching materials can think critically from the activity of observing electricity sources, classifying objects of conductors and insulators, trying to make simple electrical circuits, trying to make a simple compass and trying to make electromagnetic.

The purpose of this study is to produce scientific approach oriented science materials that are appropriate (valid, practical and effective) and can improve critical thinking of elementary school students.

\section{METHODS}

This type of research uses the Four D Models development method, namely define, design, develop and disseminate. The aim of this study is the TGT game card with material for growth and development. With define stages consist of needs analysis, student analysis, task analysis, and concept analysis. The design phase consists of determining learning objectives, preparing tests, selecting the media, and designing the initial learning. The develop phase consists of the development of learning tools and the validation of the quality of science-oriented science-based teaching materials along with related learning tools and the results of trial implementation. The trial was carried out using one group pretest-posttest design with 3 repetitions, namely 18 students at Dukuhtunggal State Elementary School, 21 students at Duduklor State Elementary School, and 16 students at grade 5 at Primary School Margoanyar for 5 meetings. The first meeting was used pretest to find out the initial ability of critical thinking of students before learning activities using science-oriented teaching materials scientific approach, the second to fourth meetings were used for learning activities using science-oriented science teaching materials, and the fifth meeting was used posttest to determine students' final critical thinking 
after following the learning activities. Research variables in this study are 1. validity of teaching materials, RPP, critical thinking tests validated by experts, 2. practicality seen from the results of observations / observations of the implementation of RPP and student activities, 3. Effectiveness seen from the results of critical thinking improvement tests students.

\section{RESULTS AND DISCUSSION}

The results of the development of science-oriented teaching materials science approach to improve critical thinking of elementary school students with supporting devices in classroom learning activities include: RPP and test results of students' thinking skills. Learning tools are said to be good if learning devices meet the criteria of feasibility, practicality, and effectiveness (Nieven, 1999. p.127). The validity of the developed learning device is declared valid or invalid using an instrument in the form of a validation sheet that will be filled by expert experts in their field, also called validators to determine the shortcomings of the devices developed and whether they are suitable for use in learning activities (Yusuf, 2016). The results of the validation of scientific approach oriented science materials developed in detail will be discussed as follows

\section{A. Results of Device Validation}

Validation of learning devices will be carried out by three Greek validators in their fields. The results obtained from the validator are used to see the level of feasibility of learning devices that have been developed before being applied in class. Devices that will be validated include learning approaches oriented to scientific approaches and related learning devices.

1. Validation of Scientific Oriented Learning Materials

Teaching material that will be developed leads to students' critical thinking skills with a scientific approach oriented by observing, asking, reasoning, trying, and communicating. Learning materials oriented to the scientific approach that have been developed are then given to the validator to be assessed. The results of the teaching material validation obtained from 3 validators are presented in table 1 . Table 1. Results of Validation of Teaching Materials

\begin{tabular}{|c|c|c|c|c|c|c|}
\hline \multirow{2}{*}{ No } & \multirow{2}{*}{ Assessment Aspect } & \multicolumn{3}{|c|}{ Score } & \multirow{2}{*}{ Average } & \multirow{2}{*}{ Category } \\
\hline & & $\mathbf{V}_{1}$ & $\mathbf{V}_{2}$ & $\mathbf{V}_{3}$ & & \\
\hline \multicolumn{7}{|c|}{ FEASIBILITY ASPECT OF THE CONTENT } \\
\hline 1 & Compatibility of material with KD & 4 & 4 & 4 & 4 & Very Valid \\
\hline 2 & Material accuracy & 3 & 3 & 3 & 3 & Valid \\
\hline 3 & Material Update & 3 & 4 & 4 & 3,66 & Very Valid \\
\hline 4 & Encourage curiosity & 4 & 3 & 4 & 3,66 & Very Valid \\
\hline \multicolumn{7}{|c|}{ SERVICE FEASIBILITY ASPECT } \\
\hline 5 & Presentation technique & 3 & 3 & 3 & 3 & Valid \\
\hline 6 & Presentation support & 3 & 4 & 4 & 3,66 & Very Valid \\
\hline 7 & Presentation of learning & 4 & 4 & 3 & 3,66 & Very Valid \\
\hline 8 & Coherence and chaos of thought & 3 & 4 & 4 & 3,66 & Very Valid \\
\hline \multicolumn{7}{|c|}{ FEASIBILITY ASPECTS OF LANGUAGES ACCORDING TO BSNP } \\
\hline 9 & Straightforward & 4 & 4 & 3 & 3,66 & Very Valid \\
\hline 10 & Communicative & 4 & 4 & 3 & 3,66 & Very Valid \\
\hline 11 & Dialogical and interactive & 3 & 4 & 4 & 3,66 & Very Valid \\
\hline 12 & Conformity with the development of students & 3 & 3 & 3 & 3 & Valid \\
\hline 13 & Conformity with language rules & 4 & 4 & 3 & 3,66 & Very Valid \\
\hline \multicolumn{7}{|c|}{ ASPECTS OF CRITICAL THINKING ASSESSMENT } \\
\hline 14 & Giving a simple explanation & 4 & 4 & 4 & 4 & Very Valid \\
\hline 15 & Building basic skills & 4 & 3 & 3 & 3,33 & Valid \\
\hline 16 & Concluding & 3 & 4 & 3 & 3,33 & Valid \\
\hline 17 & Providing an explanation & 4 & 4 & 4 & 4 & Very Valid \\
\hline 18 & Setting strategy and tactics & 3 & 4 & 4 & 3,66 & Very Valid \\
\hline \multicolumn{7}{|c|}{ CHART FEASIBILITY ASPECT } \\
\hline 19 & $\begin{array}{l}\text { The book size is oriented towards the scientific } \\
\text { approach }\end{array}$ & 4 & 3 & 3 & 3,33 & Valid \\
\hline 20 & Cover design & 4 & 4 & 4 & 4 & Very Valid \\
\hline 21 & Content design & 3 & 3 & 3 & 3 & Valid \\
\hline
\end{tabular}

From the results of the validation, it can be seen that the three validators provide an assessment that the teaching material in each aspect with an average of 3-4.

2. Validation of Learning Implementation Plans

The RPP that has been developed is then given to the validator to be assessed. The results of RPP validation 
obtained from 3 validators are presented in table 2 .

Table 2. Results of Validation of Learning Implementation Plans

\begin{tabular}{|l|l|c|c|c|c|c|}
\hline \multirow{2}{*}{ No } & \multicolumn{1}{|c|}{ Assessment Aspect } & \multicolumn{3}{c|}{ Score } & \multirow{2}{*}{ Average } & \multirow{2}{*}{ Category } \\
\cline { 3 - 6 } & & $\mathbf{V}_{\mathbf{1}}$ & $\mathbf{V}_{\mathbf{2}}$ & $\mathbf{V}_{\mathbf{3}}$ & & \\
\hline 1 & Identity & 4 & 4 & 4 & 4 & Very Valid \\
\hline 2 & Aim & 4 & 4 & 4 & 4 & Very Valid \\
\hline 3 & Scientific approach & 4 & 4 & 4 & 4 & Very Valid \\
\hline 4 & Means and sources of learning & 3 & 4 & 3 & 3,33 & Valid \\
\hline 5 & Learning Steps & 4 & 4 & 4 & 4 & Very Valid \\
\hline 6 & Cognitive aspects & 4 & 4 & 3 & 3,66 & Very Valid \\
\hline 7 & Linguistics & 3 & 3 & 3 & 3 & Valid \\
\hline
\end{tabular}

From the results of the validation it can be seen that the three validators provide an assessment that the lesson plan is in each aspect with an average of 3-4.

3. Validation Test for Student Critical Thinking

The students 'critical thinking test that has been developed is a descriptive question test that is used to measure students' critical thinking skills after learning activities. Test questions that have been developed are then given to the validator to be assessed in order to find out the feasibility of the question. The results of the test validation obtained from 3 validators are presented in table 3.

Table 3. Results of Test Question Validation

\begin{tabular}{|c|c|c|c|c|c|c|c|c|c|c|c|c|c|c|c|c|c|}
\hline \multirow{3}{*}{$\begin{array}{l}\text { Question } \\
\text { Number }\end{array}$} & \multicolumn{6}{|c|}{ Content Validation } & \multicolumn{9}{|c|}{ Bahasa dan Penulisan Soal } & \multirow{3}{*}{ Average } & \multirow{3}{*}{ Category } \\
\hline & \multicolumn{3}{|c|}{$\begin{array}{c}\text { Questions } \\
\text { according } \\
\text { to } \\
\text { indicators } \\
\end{array}$} & \multicolumn{3}{|c|}{$\begin{array}{c}\text { Measuring } \\
\text { questions } \\
\text { Critical } \\
\text { thinking } \\
\end{array}$} & \multicolumn{3}{|c|}{$\begin{array}{c}\text { Clear } \\
\text { working } \\
\text { instructions }\end{array}$} & \multicolumn{3}{|c|}{$\begin{array}{c}\text { Does not } \\
\text { contain } \\
\text { double } \\
\text { meaning } \\
\end{array}$} & \multicolumn{3}{|c|}{$\begin{array}{l}\text { The sentence } \\
\text { matches EYD } \\
\text { and is easy to } \\
\text { understand }\end{array}$} & & \\
\hline & V1 & $\mathbf{V 2}$ & V3 & V1 & V2 & V3 & V1 & V2 & $\mathbf{V 3}$ & V1 & $\mathbf{V 2}$ & V3 & V1 & V2 & V3 & & \\
\hline 1 & 4 & 4 & 4 & 4 & 4 & 4 & 3 & 4 & 4 & 4 & 4 & 4 & 3 & 4 & 4 & 3,87 & Very Valid \\
\hline 2 & 4 & 4 & 4 & 4 & 4 & 4 & 4 & 3 & 4 & 4 & 4 & 4 & 4 & 4 & 3 & 3,87 & Very Valid \\
\hline 3 & 3 & 4 & 4 & 3 & 3 & 4 & 4 & 4 & 4 & 3 & 4 & 3 & 3 & 4 & 3 & 3,53 & Valid \\
\hline 4 & 4 & 4 & 4 & 4 & 4 & 4 & 4 & 4 & 4 & 4 & 4 & 4 & 4 & 4 & 4 & 4 & Very Valid \\
\hline 5 & 4 & 4 & 4 & 4 & 4 & 4 & 4 & 4 & 4 & 4 & 4 & 4 & 4 & 4 & 4 & 4 & Very Valid \\
\hline 6 & 4 & 4 & 4 & 4 & 4 & 3 & 4 & 4 & 3 & 4 & 4 & 4 & 4 & 3 & 4 & 3,8 & Very Valid \\
\hline 7 & 4 & 4 & 4 & 4 & 4 & 4 & 4 & 4 & 4 & 4 & 4 & 4 & 4 & 4 & 4 & 4 & Very Valid \\
\hline 8 & 3 & 3 & 3 & 4 & 4 & 4 & 3 & 4 & 3 & 4 & 4 & 4 & 3 & 3 & 4 & 3,53 & Valid \\
\hline 9 & 4 & 4 & 4 & 3 & 4 & 3 & 4 & 4 & 4 & 4 & 4 & 4 & 4 & 4 & 3 & 3,8 & Very Valid \\
\hline 10 & 4 & 4 & 4 & 4 & 4 & 4 & 4 & 4 & 4 & 4 & 4 & 4 & 4 & 4 & 4 & 4 & Very Valid \\
\hline 11 & 4 & 4 & 4 & 4 & 4 & 4 & 3 & 4 & 3 & 4 & 3 & 4 & 4 & 4 & 4 & 3,8 & Very Valid \\
\hline 12 & 4 & 4 & 4 & 4 & 4 & 4 & 4 & 4 & 4 & 4 & 4 & 4 & 4 & 4 & 4 & 4 & Very Valid \\
\hline 13 & 4 & 4 & 4 & 4 & 4 & 4 & 4 & 4 & 4 & 4 & 4 & 4 & 4 & 4 & 4 & 4 & Very Valid \\
\hline
\end{tabular}

From the results of the validation it can be seen that the three validators gave an assessment that the test questions were critical in every aspect with an average of 3.53-4.

\section{B. Results of practicality of scientific approach oriented science materials}

The results of the practicality of science-based teaching materials with scientific approach are seen from the results of the implementation of learning activities carried out and student activities during the learning activities taking place with observation by 2 observers.

1. Results of Implementation of Learning Activities

The results of observations on the implementation of learning activities using science-oriented science approach teaching materials that have been developed will be analyzed at each meeting described as follows: The results of observational analysis that has been done on the implementation of meeting 1 learning activities get a percentage between $83 \%$ - 92\%, Results Observation analysis that has been done on the implementation of meeting 2 learning activities gets a percentage between $88 \%-100 \%$, and the results of the observational analysis that has been carried out on the implementation of the 3 meeting 3 learning activities get a percentage between $88 \%-100 \%$. In summary, the results of observing the implementation of lesson plans for 3 weeks can be shown in Figure. 


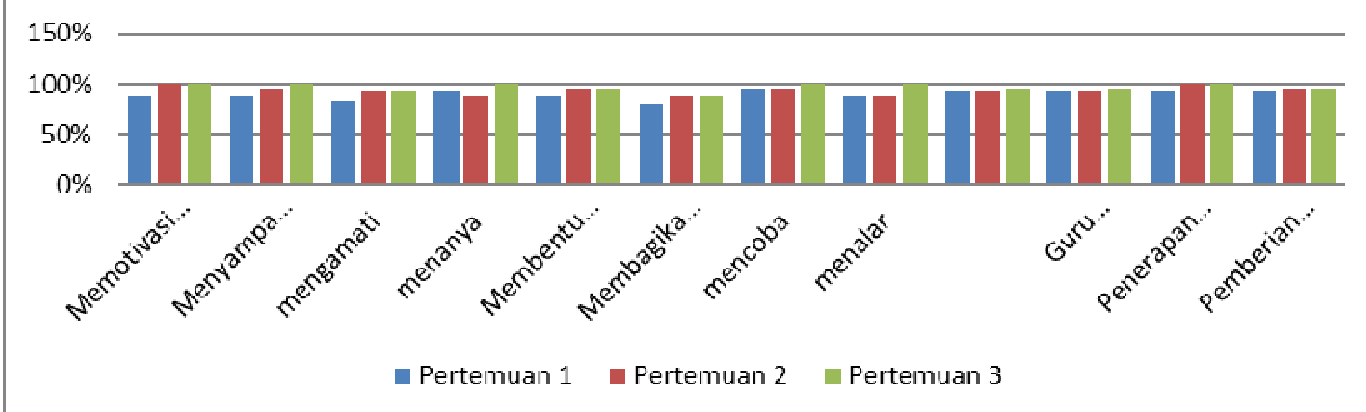

Figure 1. Diagram of the results of observing the implementation of the lesson plan

2. Results of Student Activity Analysis

The results of the analysis of student activities during learning activities were observed by two observers in each meeting consisting of 10 aspects with the discussion of the results of the assessment by the two observers as follows: the percentage between $83 \%-100 \%$, meeting 2 gets a percentage between $88 \%-100 \%$, and meeting 3 gets a percentage between $92 \%-100 \%$. In summary, the results of observing student activities for 3 weeks can be displayed in Figure. 4.5.

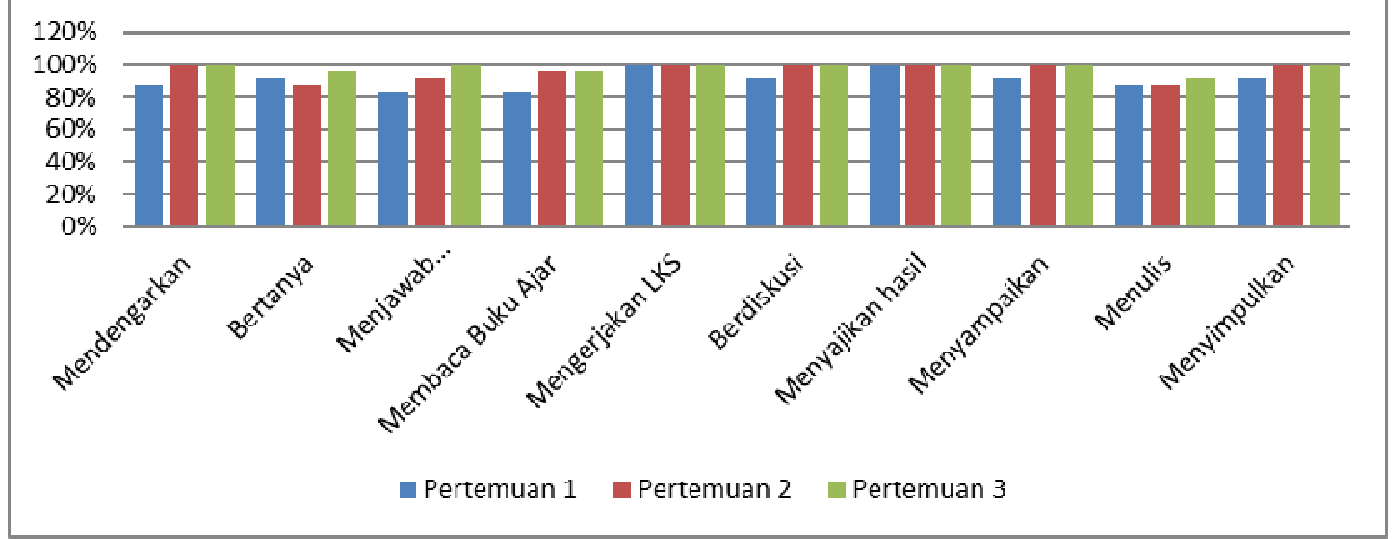

Figure 3. Diagram of observation of student activities

The observations of student activities from meetings 1-3 if related to the criteria for implementing learning adopted (Riduwan, 2011) found that the use of teaching materials oriented to the scientific approach in the category of active assessment in learning activities. According to Suyono (2016) regarding learning to find students who support learning related to direct discovery, teachers only encourage students to have experience and conduct experiments that allow them to think critically for themselves (Nur, 2008, p. 10).

So it can be concluded that the scientific approach oriented teaching materials developed by practical researchers are used in the learning process.

\section{Effectiveness of Scientific Learning Approach Scientific Approach}

The effectiveness of scientific approach oriented science materials can be seen from the results of students' critical thinking tests. Tests are arranged as many as 13 questions with scoring techniques in accordance with the rubric that has been prepared previously. Arikunto Opinion (2013, p. 46) tests are skills, knowledge, abilities and talents possessed by individuals or groups that can be obtained through a collection of questions or exercises and other tools. this learning outcome test is conducted before the learning (pretest) and after learning (posttest) with the same problem. Tests conducted before learning are intended to obtain information on the level of critical thinking of students before learning using teaching materials, while tests conducted after learning aim to measure the extent to which mastery of critical thinking is mastered by students after carrying out learning. This is in accordance with Winarti $(2015, \mathrm{p} .10)$ stated that critical thinking is measured from the score obtained by a series of opinion learning activities in line with what Wuri stated (2014) to find out the difference in critical thinking of students obtained from the pretest and posttest from the learning done. The results of the pretest and pottest results of critical thinking learning in the trials are presented in table 4. 
Table 4. Data on students' critical thinking learning outcomes

\begin{tabular}{|c|c|c|c|c|c|c|c|c|}
\hline \multirow{2}{*}{ No } & \multirow{2}{*}{ Name } & \multicolumn{2}{|c|}{ Score } & \multirow{2}{*}{ KKM } & \multicolumn{2}{|c|}{ Completeness } & \multirow{2}{*}{ N-Gain } & \multirow{2}{*}{ Informatior } \\
\hline & & Pretest & Posttest & & Pretest & Posttest & & \\
\hline & Repetition 1 & & & & & & & \\
\hline 1 & AA & 25 & 88 & 70 & TT & $\mathrm{T}$ & 0,84 & High \\
\hline 2 & $\mathrm{BB}$ & 31 & 90 & 70 & TT & $\mathrm{T}$ & 0,85 & High \\
\hline 3 & $\mathrm{CC}$ & 33 & 83 & 70 & TT & $\mathrm{T}$ & 0,74 & High \\
\hline 4 & DD & 25 & 75 & 70 & TT & $\mathrm{T}$ & 0,67 & Medium \\
\hline 5 & $\mathrm{EE}$ & 44 & 80 & 70 & $\mathrm{TT}$ & $\mathrm{T}$ & 0,64 & Medium \\
\hline 6 & $\mathrm{FF}$ & 42 & 85 & 70 & TT & $\mathrm{T}$ & 0,74 & High \\
\hline 7 & GG & 35 & 79 & 70 & TT & $\mathrm{T}$ & 0,68 & Medium \\
\hline 8 & $\mathrm{HH}$ & 48 & 85 & 70 & TT & $\mathrm{T}$ & 0,71 & High \\
\hline 9 & II & 73 & 85 & 70 & $\mathrm{~T}$ & $\mathrm{~T}$ & 0,44 & Medium \\
\hline 10 & $\mathrm{JJ}$ & 38 & 79 & 70 & TT & $\mathrm{T}$ & 0,66 & Medium \\
\hline 11 & KK & 75 & 92 & 70 & $\mathrm{~T}$ & $\mathrm{~T}$ & 0,68 & Medium \\
\hline 12 & LL & 37 & 83 & 70 & TT & $\mathrm{T}$ & 0,73 & High \\
\hline 13 & MM & 40 & 81 & 70 & TT & $\mathrm{T}$ & 0,68 & Medium \\
\hline 14 & $\mathrm{NN}$ & 35 & 83 & 70 & TT & $\mathrm{T}$ & 0,74 & High \\
\hline 15 & $\mathrm{OO}$ & 31 & 85 & 70 & TT & $\mathrm{T}$ & 0,78 & High \\
\hline 16 & $\mathrm{PP}$ & 25 & 79 & 70 & $\mathrm{TT}$ & $\mathrm{T}$ & 0,72 & High \\
\hline 17 & QQ & 31 & 77 & 70 & TT & $\mathrm{T}$ & 0,67 & Medium \\
\hline \multirow[t]{2}{*}{18} & RR & 33 & 81 & 70 & TT & $\mathrm{T}$ & 0,72 & High \\
\hline & Repetition 2 & & & & & & & \\
\hline 1 & $\mathrm{AA}$ & 29 & 85 & 70 & TT & $\mathrm{T}$ & 0,78 & High \\
\hline 2 & $\mathrm{BB}$ & 35 & 77 & 70 & TT & $\mathrm{T}$ & 0,64 & Medium \\
\hline 3 & $\mathrm{CC}$ & 37 & 85 & 70 & TT & $\mathrm{T}$ & 0,76 & High \\
\hline 4 & DD & 71 & 87 & 70 & $\mathrm{~T}$ & $\mathrm{~T}$ & 0,55 & Medium \\
\hline 5 & $\mathrm{EE}$ & 27 & 79 & 70 & TT & $\mathrm{T}$ & 0,71 & High \\
\hline 6 & $\mathrm{FF}$ & 73 & 90 & 70 & $\mathrm{~T}$ & $\mathrm{~T}$ & 0,62 & Medium \\
\hline 7 & GG & 71 & 85 & 70 & $\mathrm{~T}$ & $\mathrm{~T}$ & 0,48 & Medium \\
\hline 8 & $\mathrm{HH}$ & 35 & 79 & 70 & TT & $\mathrm{T}$ & 0,68 & Medium \\
\hline 9 & II & 73 & 87 & 70 & $\mathrm{~T}$ & $\mathrm{~T}$ & 0,52 & Medium \\
\hline 10 & $\mathrm{JJ}$ & 33 & 81 & 70 & TT & $\mathrm{T}$ & 0,72 & High \\
\hline 11 & KK & 40 & 83 & 70 & TT & $\mathrm{T}$ & 0,72 & High \\
\hline 12 & LL & 35 & 79 & 70 & TT & $\mathrm{T}$ & 0,68 & Medium \\
\hline 13 & MM & 75 & 88 & 70 & $\mathrm{~T}$ & $\mathrm{~T}$ & 0,52 & Medium \\
\hline 14 & NN & 35 & 83 & 70 & TT & $\mathrm{T}$ & 0,74 & High \\
\hline 15 & $\mathrm{OO}$ & 31 & 85 & 70 & TT & $\mathrm{T}$ & 0,78 & High \\
\hline 16 & $\mathrm{PP}$ & 25 & 85 & 70 & TT & $\mathrm{T}$ & 0,80 & High \\
\hline 17 & QQ & 48 & 90 & 70 & TT & $\mathrm{T}$ & 0,81 & High \\
\hline 18 & RR & 33 & 79 & 70 & TT & $\mathrm{T}$ & 0,69 & Medium \\
\hline 19 & SS & 25 & 77 & 70 & TT & $\mathrm{T}$ & 0,69 & Medium \\
\hline 20 & TT & 48 & 80 & 70 & TT & $\mathrm{T}$ & 0,62 & Medium \\
\hline \multirow[t]{2}{*}{21} & UU & 29 & 85 & 70 & TT & $\mathrm{T}$ & 0,78 & High \\
\hline & Repetition 3 & & & & & & & \\
\hline 1 & $\mathrm{AA}$ & 33 & 83 & 70 & TT & $\mathrm{T}$ & 0,75 & High \\
\hline 2 & $\mathrm{BB}$ & 40 & 81 & 70 & TT & $\mathrm{T}$ & 0,68 & Medium \\
\hline 3 & $\mathrm{CC}$ & 35 & 83 & 70 & TT & $\mathrm{T}$ & 0,74 & High \\
\hline 4 & DD & 31 & 85 & 70 & TT & $\mathrm{T}$ & 0,78 & High \\
\hline 5 & $\mathrm{EE}$ & 25 & 79 & 70 & TT & $\mathrm{T}$ & 0,72 & High \\
\hline 6 & $\mathrm{FF}$ & 31 & 88 & 70 & TT & $\mathrm{T}$ & 0,83 & High \\
\hline 7 & GG & 33 & 83 & 70 & TT & $\mathrm{T}$ & 0,74 & High \\
\hline 8 & $\mathrm{HH}$ & 35 & 75 & 70 & TT & $\mathrm{T}$ & 0,62 & Medium \\
\hline 9 & II & 44 & 80 & 70 & TT & $\mathrm{T}$ & 0,64 & Medium \\
\hline 10 & $\mathrm{JJ}$ & 46 & 85 & 70 & TT & $\mathrm{T}$ & 0,72 & High \\
\hline 11 & KK & 35 & 77 & 70 & TT & $\mathrm{T}$ & 0,64 & Medium \\
\hline 12 & $\mathrm{LL}$ & 37 & 83 & 70 & TT & $\mathrm{T}$ & 0,73 & High \\
\hline 13 & MM & 77 & 92 & 70 & $\mathrm{~T}$ & $\mathrm{~T}$ & 0,65 & Medium \\
\hline 14 & $\mathrm{NN}$ & 35 & 79 & 70 & TT & $\mathrm{T}$ & 0,68 & Medium \\
\hline 15 & $\mathrm{OO}$ & 73 & 88 & 70 & $\mathrm{~T}$ & $\mathrm{~T}$ & 0,56 & Medium \\
\hline 16 & $\mathrm{PP}$ & 38 & 85 & 70 & TT & $\mathrm{T}$ & 0,76 & High \\
\hline
\end{tabular}

Based on the results obtained in table 4 that the value obtained by students between the pretest and posttest 
values increased. Critical thinking improvement can be seen from N-Gain which is in the medium and high category. The following is explained the recapitulation of students' critical thinking improvement in Table 5.

\begin{tabular}{clcc}
\multicolumn{4}{c}{ Table 5. Recapitulation of improvement in students' critical thinking seen from N-Gain } \\
\hline No & N-Gain Category & Number of Students & Precentage (\%) \\
1 & Low & 0 & $0 \%$ \\
2 & Medium & 26 & $47 \%$ \\
3 & High & 29 & $53 \%$ \\
\hline
\end{tabular}

The results obtained by students when looking at table 4.14 shows that students 'critical thinking obtained after learning activities uses science-oriented science approaches with medium approach, namely 26 students with a percentage of $47 \%$ and high category ie 29 students with a percentage of $53 \%$ said to improve students' critical thinking. This is in accordance with the results of research proposed by Rusiyanti's research, E (2016) which states that a scientific approach is very effective in learning where students can reflect students' critical experiences and thoughts on an object so that they can improve critical thinking and student achievement.

\section{CONCLUSSION}

The results of the data analysis and discussion of the results of the study, then linked to the formulation of the problem and research objectives, it can be concluded that:

1. The validity of scientific approach oriented learning materials and learning devices developed has fulfilled the validity criteria based on the results of evaluations from the validator so that the instructional materials developed are suitable for learning activities.

2. The practicality of scientific approach oriented science teaching material developed seen from its implementation in learning, has been carried out very well at meeting 1 , meeting 2 , and meeting 3 , at each learning activity.

3. The effectiveness of scientific approach oriented science teaching materials that are developed seen from the results of critical thinking learning students experience improvement and excellent student responses, so that it can be said to be worthy of use in learning activities

\section{Suggestion}

1. Preparation and management of time need to be considered, because the learning used to use the project takes a long time.

2. If you want to improve critical thinking students use scientific approach oriented teaching materials that have been tested to improve critical thinking of elementary school students.

3. Teachers should make innovations in learning so learning becomes enjoyable so that they can touch meaningful learning domains.

4. This research can hopefully be used as a foundation for future researchers to be better developed to improve the quality of education in Indonesia.

\section{REFERENCE LIST}

Afrizon, A. 2012. Peningkatan Perilaku Berkarakter dan Ketrampilan Berpikir Kritis Siswa Kelas IX MTsN Model Padang Pada Mata Pelajaran IPA-Fisika Menggunakan Model Problem Based Instruction. Jurnal Penelitian Pembelajaran Fisika, 2 (1): 1-16.

Arikunto, S. 2013. Prosedur Penelitian: Suatu Pendekatan Praktek. Jakarta: Rineka Cipta

Djojosoediro, Wasih. 2010. Hakikat IPA dan Pembelajaran IPA di SD. Modul. Tidak Diterbitkan.

Erten, S., Kiray, S.A., \& Sen-Gumus, B. (2013). Influence of scientific stories on students ideas about science and scientists. International Journal of Education in Mathematics, Science and Technology, 1(2), 122-137.

Fahim, M \& Pezeshki, M. 2012. Manipulating Critical Thingking Skills in Test Taking. International Journal of Education. Vol 4, No 1, Hal 153-160.

Fatmawati, Harlinda. 2014. Analisis Berpikir Kritis Siswa Dalam Pemecahan Masalah Matematika Berdasarkan Polya Pada Pokok Bahasan Persamaan Kuadrat. Jurnal Elektronik Pembelajaran Matematika Vol.2, No.9, hal 899-910.

Fisher, Alec. 2002. Berpikir Kritis Sebuah Pengantar. Jakarta: Erlangga.

Hake. 1999. Analyzing Chang/ Gain Score. Tersedia www.physics.indiana.edu/ sdi/AnalyzingChange-Gain.pdf. Diakses tanggal 2 Desember 2018

Kemendikbud, 2013. Implementasi Kurikulum 2013. Jakarta: Kementrian Pendidikan dan Kebudayaan RI.

Machin, A. 2014. Implementasi Pendekatan Saintifik, Penanaman Karakter Dan Konservasi Pada Pembelajaran Materi Pertumbuhan. Indonesian Journal of Science Education. Vol.3, No.1. DOI: https://doi.org/10.15294/jpii.v3i1.2898

Muakhirin, Binti. (2014). Peningkatan Hasil Belajar IPA Melalui Pendekatan Pembelajaran Inkuiri Pada Siswa SD.

Nieven N. 1999. Prototype to Read Product Quality: Design Approaches and Tools in Education and Training. 
Netherland: Springer- Science+Business Media, B.V.

Nur, M. 2008. Pengajaran Berpusat Kepada Siswa Dan Pendekatan Konstruktivis Dalam Pengajaran. Surabaya: Unesa University Press.

Prastowo, Andi. 2011. Panduan Kreatif Membuat Bahan Ajar Inovatif (menciptakan metode pembelajaran yang menarik dan menyenangkan). Yogyakarta: Diva Press.

Ratumanan, Tanwet Gerson dan Theresia Laurens. 2015. Penilaian Hasil Belajar pada Tingkat Satuan Pendidikan Edisi 3. Yogyakarta: Pensil Komunika.

Riduwan. 2011. Belajar Mudah Penelitian untuk Guru-Karyawan dan Peneliti Pemula. Bandung: Alfabeta.

Rofiah, dkk. 2013. Penyusunan Instrumen Tes Kemampuan Berpikir Tingkat Tinggi Fisika Pada Siswa SMP. Jurnal Pendidikan Fisika, Volume 1 No.2, Hlm. 17-22.

Rusiyanti, E. (2016). Pengaruh pendekatan saintifik terhadap prestasi belajar siswa pada mata pelajaran IPS kleas VIII E di SMP Negeri 24 Surabaya. (Tesis Master). Surabaya: Universitas Negeri Surabaya. Tersedia di : http://ejournal.unesa.ac.id/index.php/avatara/article/view/16952.

Slavin, E. R. 2011. Educational Psychology; Theory and Practice. USA; Pearson.

Sugiyono. 2016. Metode Penelitian Pendidikan. Bandung: Alfabeta/ Jakarta: Rineka Cipta

Susanto, A. 2016. Teori Belajar dan Pembelajaran di Sekolah Dasar. Jakarta: Kencana.

Wuri, O.R dan Mulyaningsih, S. 2014. Penerapan Pendekatan Saintifik Pada Pembelajaran Fisika Materi Kalor Terhadap Keterampilan Berpikir Kritis Siswa Kelas X SMA. Jurnal Inovasi Pendidikan Fisika (JIPF). Vol. 03 No. 03 Tahun 2014, 91-95

Yusuf, Muhammad. 2016. Pengembangan Perangkat Pembelajaran IPA Berbasis Keterampilan Proses Untuk Meningkatkan Keterampilan Berpikir Kritis Siswa Sekolah Dasar. (Tesis). Surabaya; Universitas Negeri Surabaya.

\section{AUTHORS}

First Author - A. Indra Nihlah Annashih, Post Graduate, Universitas Negeri Surabaya

Second Author - Tjandra Kirana, Lecturer, Universitas Negeri Surabaya

Third Author - Raharjo, Lecturer, Universitas Negeri Surabaya 